\title{
Detection and classification of laminae in balloon-borne ozonesonde profiles: application to the long-term record from Boulder, Colorado
}

\author{
Kenneth Minschwaner $^{1}$, Anthony T. Giljum ${ }^{2}$, Gloria L. Manney ${ }^{3,1}$, Irina Petropavlovskikh ${ }^{4,5}$, Bryan J. Johnson ${ }^{5}$, and \\ Allen F. Jordan ${ }^{4,5}$ \\ ${ }^{1}$ Department of Physics, New Mexico Institute of Mining and Technology, Socorro, New Mexico, USA \\ ${ }^{2}$ Departments of Applied Physics and Electrical Engineering, Rice University, Houston, Texas, USA \\ ${ }^{3}$ NorthWest Research Associates, Socorro, New Mexico, USA \\ ${ }^{4}$ CIRES, University of Colorado, Boulder, Colorado, USA \\ ${ }^{5}$ Global Monitoring Division, NOAA/ESRL, Boulder, Colorado, USA
}

Correspondence: Kenneth Minschwaner (kenneth.minschwaner@nmt.edu)

Received: 27 August 2018 - Discussion started: 4 October 2018

Revised: 12 January 2019 - Accepted: 15 January 2019 - Published: 12 February 2019

\begin{abstract}
We quantify ozone variability in the upper troposphere and lower stratosphere (UTLS) by investigating lamination features in balloon measurements of ozone mixing ratio and potential temperature. Laminae are defined as stratified variations in ozone that meet or exceed a $10 \%$ threshold for deviations from a basic state vertical profile of ozone. The basic state profiles are derived for each sounding using smoothing methods applied within a vertical coordinate system relative to the World Meteorological Organization (WMO) tropopause. We present results of this analysis for the 25-year record of ozonesonde measurements from Boulder, Colorado. The mean number of ozone laminae identified per sounding is about $9 \pm 2(1 \sigma)$. The root-mean-square relative amplitude is $20 \%$, and laminae with much larger amplitudes $(>40 \%)$ are seen in $\sim 2 \%$ of the profiles. The vertical scale of detected ozone laminae typically ranges between 0.5 and $1.2 \mathrm{~km}$. The lamina occurrence frequency varies significantly with altitude and is largest within $\sim 2 \mathrm{~km}$ of the tropopause. Overall, ozone laminae identified in our analysis account for more than one-third of the total intra-seasonal variability in ozone. A correlation technique between ozone and potential temperature is used to classify the subset of ozone laminae that are associated with gravity wave $(\mathrm{GW})$ phenomena, which accounts for $28 \%$ of all laminar ozone features. The remaining $72 \%$ of laminae arise from nongravity wave (NGW) phenomena. There are differences in both the vertical distribution and seasonality of $\mathrm{GW}$ versus
\end{abstract}

NGW ozone laminae that are linked to the contrast in main generating mechanisms for each laminae type.

\section{Introduction}

The day-to-day variability in the vertical distribution of ozone $\left(\mathrm{O}_{3}\right)$ above a fixed location is often characterized by the presence of transient, stratified features (e.g., Dütsch, 1966). The stratification occurs in the form of layered maxima and minima in the observed vertical profile of ozone, with typical vertical scales between about $\sim 0.2$ and $\sim 3 \mathrm{~km}$ (e.g., Dobson, 1973; Ehhalt et al., 1983). These features are generally called ozone laminae (e.g., Reid and Vaughan, 1991; Teitelbaum et al., 1994; Orsolini, 1995; Appenzeller and Holton, 1997; Manney et al., 1998, 2000). Laminar structures in $\mathrm{O}_{3}$ have been observed in both the troposphere and stratosphere, and their generation can be linked to a wide range of mechanisms such as stratosphere-troposphere exchange, tropical and monsoon-related deep convection, gravity waves, differential advection of ozone fields within natural spatial gradients, photochemical production or loss, and advection of urban plumes (e.g., Thompson et al., 2011; and references therein). The horizontal scales of laminae can vary significantly, but generally they are observed over tens to hundreds of kilometers, leading to tracer features such as 
tongues or filaments appearing in quasi-horizontal coordinates (e.g., Randel et al., 1993; Waugh, 1996; Bowman et al., 2007; Fairlie et al., 2007; Manney et al., 1998).

The most important dynamical processes that generate ozone laminae in the midlatitude upper troposphere (UT, defined here from $\sim 5 \mathrm{~km}$ altitude to the tropopause) are gravity and Rossby waves, convective lofting and detrainment of either high or low $\mathrm{O}_{3}$ from the lower atmosphere, and intrusions of air masses with high ozone concentrations from the stratosphere (e.g., Langford and Reid, 1998; Thompson et al., 2007b; Selkirk et al., 2010). These generating mechanisms often involve nonlocal dynamics and long-range transport by UT jets, and in some cases the ozone anomalies have been traced back to dynamical events occurring thousands of kilometers from the measurement location (e.g., Vogel et al., 2014; Minschwaner et al., 2015). In the midlatitude lower stratosphere (LS, defined here from the tropopause to $\sim 22 \mathrm{~km}$ ), gravity waves, tropospheric intrusions, and differential advection have been identified as drivers of ozone laminae (Teitelbaum et al., 1994; Manney et al., 1998, 2000; Pierce and Grant, 1998; Tomikawa et al., 2002; Pan et al., 2009; Olson et al., 2010). For regions of the atmosphere where the time constants for photochemical production and loss of ozone are longer than dynamical timescales, e.g., at least a week in the UT (Liu et al., 1980) and a month in the LS (e.g., Shimizaki, 1984), observations of ozone laminae are evidence of predominantly transport-related phenomena.

A better understanding of the characteristics of ozone laminae and their generating mechanisms is needed in order to fully characterize ozone variability and long-term changes in the upper troposphere and lower stratosphere (UTLS). This understanding is critical for assessing the radiative forcing of climate by ozone and for evaluating the impact of transport on regional air quality. Here, we describe a new method for identifying and classifying ozone laminae from high vertical resolution measurements $(\sim 100 \mathrm{~m})$ of ozone, pressure, and temperature. The techniques have been derived and tested on vertical profiles obtained from balloon soundings, but they can be generalized to other trace gas datasets with sufficient vertical resolution. We present an application of this method to the long-term record (1991-present) of ozonesonde profiles from Boulder, Colorado.

\section{Dataset}

Ozonesonde data are obtained from an in situ sensor that is flown on a balloon in a package that includes radiosonde and GPS devices (Komhyr, 1986; Komhyr at al., 1995). An ozonesonde consists of a Teflon air pump and an electrochemical ozone sensor (ECC) with two platinum electrodes in separate cells of potassium iodide solutions with different concentrations. Ambient air is drawn through one cell and the presence of $\mathrm{O}_{3}$ drives chemical reactions that give rise to a microampere current between the electrodes. A complete description of the ECC ozonesonde is given in Komhyr et al. (1995). Output from the ECC is interfaced to a meteorological radiosonde, which measures air temperature, pressure, relative humidity, and GPS position, and transmits all of the ozone and meteorological data back to a ground receiving station during the $\sim 2 \mathrm{~h}$ balloon ascent. Raw data are taken at $\sim 1 \mathrm{~s}$ resolution during the flight up to the burst altitude, which is typically at or above $30 \mathrm{~km}$. The precision in ozone mixing ratios in the UTLS region is $3 \%-5 \%(1 \sigma)$, and the absolute accuracy is about $10 \%$. The combined effect from the sensor time response in the UTLS $(\sim 25 \mathrm{~s})$ and the balloon ascent rate $\left(4-5 \mathrm{~m} \mathrm{~s}^{-1}\right)$ gives an effective vertical resolution of about $100 \mathrm{~m}$ (Hassler et al., 2014, and references therein). Although some data may be available during the parachute descent phase of the sounding, the ascending flight data are considered the highest quality; mixing ratio profiles used here are from ascent only and are vertically averaged within $100 \mathrm{~m}$ thick layers.

Ozonesonde data from Boulder, Colorado $\left(40^{\circ} \mathrm{N}, 105^{\circ} \mathrm{W}\right.$; $1.7 \mathrm{~km}$ a.s.l.), are available from 1978 to present, with approximately weekly sampling. The data since 1991 have been homogenized by applying instrumental corrections including effects of different buffer solutions (Komhyr et al., 1995; Smit et al., 2007; Deshler et al., 2008) and effects from Teflon air pump efficiencies (Johnson et al., 2002; Deshler et al., 2017). Homogenization of NOAA ozonesonde records to remove instrumental inconsistencies is described by Sterling et al. (2018). Prior to 1991, the data are digitized from charts and are available at $1 \mathrm{~min}$ time resolution $(\sim 250 \mathrm{~m}$ effective vertical resolution). For consistency in vertical resolution and data quality, we limit our analysis here to the post-1991 ozone data from Boulder.

\section{Methods}

A qualitative description of laminae in a vertical profile of $\mathrm{O}_{3}$ can usually be made by visual inspection, but a quantitative and objective assessment requires a set of criteria for defining ozone perturbations as deviations from some basic state. Figure 1 shows balloon profiles of ozone mixing ratio $(\chi)$ and potential temperature $(\Theta)$ observed from Boulder on 10 June 2008. Both profiles contain laminar structures that are easily discernible by eye. For a quantitative analysis of such profiles, we developed an analysis package called RIO SOL (Robust Identification of Observed Signatures in Ozone Laminae), which applies a consistent filtering method (described below) to every profile in order to find basic states for ozone mixing ratio $\left(\chi_{\mathrm{s}}\right)$ and potential temperature $\left(\Theta_{\mathrm{s}}\right)$. All perturbations are then defined in terms of differences (i.e., $\chi^{\prime}=\chi-\chi_{\mathrm{s}}$ ), and a lamina is identified when the relative anomaly in ozone is at least $10 \%$ (i.e., $\left|\chi^{\prime}\right| \chi_{\mathrm{s}} \mid \geq 0.1$; see Fig. 1). This amplitude threshold for defining laminae is broadly consistent with previous analyses (Teitelbaum et al., 1994; Grant et al., 1998; Thompson et al., 2007a), but our 


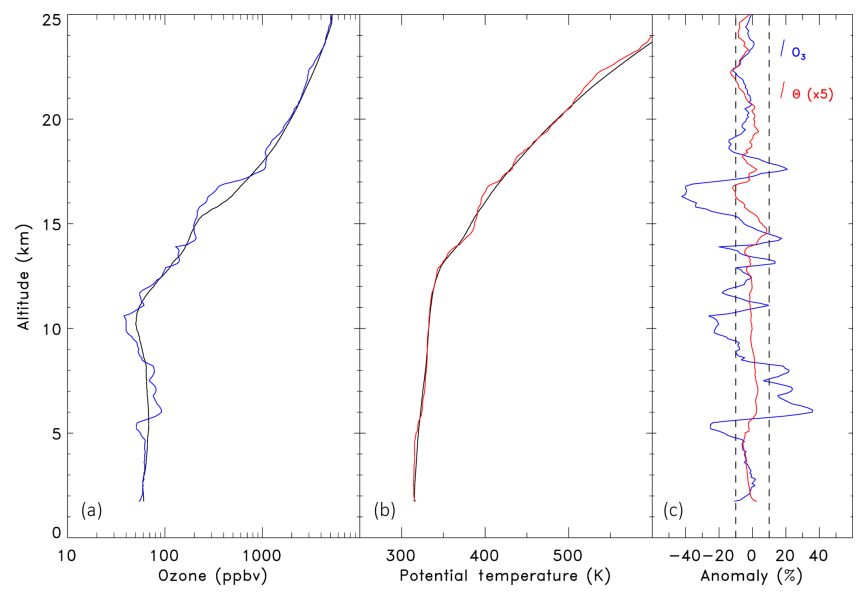

Figure 1. Vertical profiles of ozone (a, solid blue) and potential temperature (b, solid red) measured from Boulder, CO on 10 June 2008. The respective basic states are indicated by solid black curves in both panels. Panel (c) shows relative anomalies based on differences between the measured and basic state profiles for ozone (solid blue) and potential temperature (solid red, scaled by a factor of 5). Dashed vertical lines denote the $\pm 10 \%$ threshold in ozone anomaly that is used to identify lamina.

approach for deriving the basic state is modified to improve detection and identification of laminae located within a few kilometers of the thermal tropopause.

Dobson (1973) and Reid and Vaughan (1991) used a direct sampling method to locate extrema in the vertical profile of ozone partial pressure. They defined a lamina as a local maximum or minimum in ozone that exceeded $20 \mathrm{nb}$ in peak magnitude, with a full width between 0.2 and $2.0 \mathrm{~km}$ (defined with respect to upper and lower "turning points" bracketing the layer). The use of an absolute threshold rather than a relative one to define a lamina was related to their use of ozone partial pressures, as the change in ozone partial pressure between the troposphere and stratosphere is much less than the corresponding change in ozone mixing ratio. However, a fixed $20 \mathrm{nb}$ threshold in partial pressure is roughly comparable to our $10 \%$ threshold in mixing ratio only in the middle stratosphere, between about 20 and $30 \mathrm{~km}$ altitude. In the UT, mean ozone partial pressures are much lower (25-40 nb) and the same $20 \mathrm{nb}$ threshold will only detect those anomalies that are larger than 50\%-80\%. With such a reduced sensitivity, the number of lamina detections in the UT should be smaller than the number of UT laminae we identify using a $10 \%$ mixing ratio threshold. Krizan and Lastovicka (2005) and Krizan et al. (2015) used an even larger threshold of $40 \mathrm{nb}$ in peak magnitude to examine "strong" ozone laminae in vertical profiles. Alternatively, Huang et al. (2015) used a continuous wavelet transform (CWT) approach to study ozone laminae in lidar ozone vertical profiles. An interesting feature of the CWT approach is that it does not use a basic state or reference ozone profile to identify laminae. The laminae amplitude thresholds used by Huang et al. (2015) were
$10 \mathrm{ppbv}$ in the troposphere and $40 \mathrm{ppbv}$ in the stratosphere, which more closely follows our $10 \%$ threshold than the partial pressure criteria discussed above.

Reid and Vaughan (1991) and Huang et al. (2015) compared their methods to "filter and difference" techniques that are broadly similar to the approach used here and in other studies (e.g., Grant et al., 1998; Krizan and Lastovicka, 2005; Thompson et al., 2007a) and found reasonable agreement in lamina statistics between the two methods. One advantage of the filter and difference approach is that basic states are generated for each profile, as described below, which can provide important information on the contribution of laminae to the overall variability in ozone.

An important drawback to filtering, however, is directly tied to sharp changes in the vertical gradients of ozone and potential temperature near the tropopause. Figure 2 shows observed $\chi$ and $\Theta$ profiles along with two sets of basic state profiles, $\left(\chi_{\mathrm{s} 1}, \Theta_{\mathrm{s} 1}\right)$ and $\left(\chi_{\mathrm{s} 2}, \Theta_{\mathrm{s} 2}\right)$. The first set of basic states is derived by applying a nonrecursive boxcar filter with a fixed width of $6 \mathrm{~km}$ to each observed profile. A fixed-width filter has been employed in a number of previous studies (e.g., Teitelbaum et al., 1994), and for a $6 \mathrm{~km}$ boxcar the effective low-pass filter cutoff frequency $(\sim 90 \%$ level) corresponds to vertical scales of $2-3 \mathrm{~km}$. These basic states are thus smoothed profiles with all features at scales less than $\sim 2.5 \mathrm{~km}$ effectively removed (dashed curves in Fig. 2). Subsequent differencing with the observed profiles produces anomaly profiles that emphasize laminar features less than $2.5 \mathrm{~km}$ in width. Note that our $0.1 \mathrm{~km}$ averaging and sampling grid for the measurement profiles corresponds to an effective Nyquist cutoff for scales less than $0.2 \mathrm{~km}$; thus, this method for laminae identification is focused on features with widths between about 0.2 and $2.5 \mathrm{~km}$. Features that span a vertical range larger than about $3 \mathrm{~km}$ occupy a significant fraction of the density scale height, and are more often related to large-scale shifts in air masses than to processes typically associated with the generation of laminae (Reid and Vaughan, 1991). At vertical scales below $0.2 \mathrm{~km}$, however, an important contribution to ozone variability could result from the presence of very thin laminae. Aircraft measurements of tracer variability have indicated scale-invariant behavior over a wide range of horizontal scales, ranging from 0.2 to $2700 \mathrm{~km}$ (Tuck et al., 2004). Although this suggests that vertical scales below $0.2 \mathrm{~km}$ may be important, the variability in ozone at horizontal and vertical scales less than $0.2 \mathrm{~km}$ is not well characterized in the UTLS region.

The method of fixed-width filtering consistently produces an apparent lamina of negative sign near the tropopause level (Fig. 2). In this case, the effective $\mathrm{O}_{3}$ and $\Theta$ perturbations are always less than basic state values due to sharp changes in the vertical gradients of both quantities near the tropopause. Rapid gradient changes near the tropopause usually occur on scales less than $2.5 \mathrm{~km}$ and therefore are smoothed out in a basic state derived from a $6 \mathrm{~km}$ wide filter. A similar effect was noted by Schmidt et al. (2008) in their analysis of gravity 

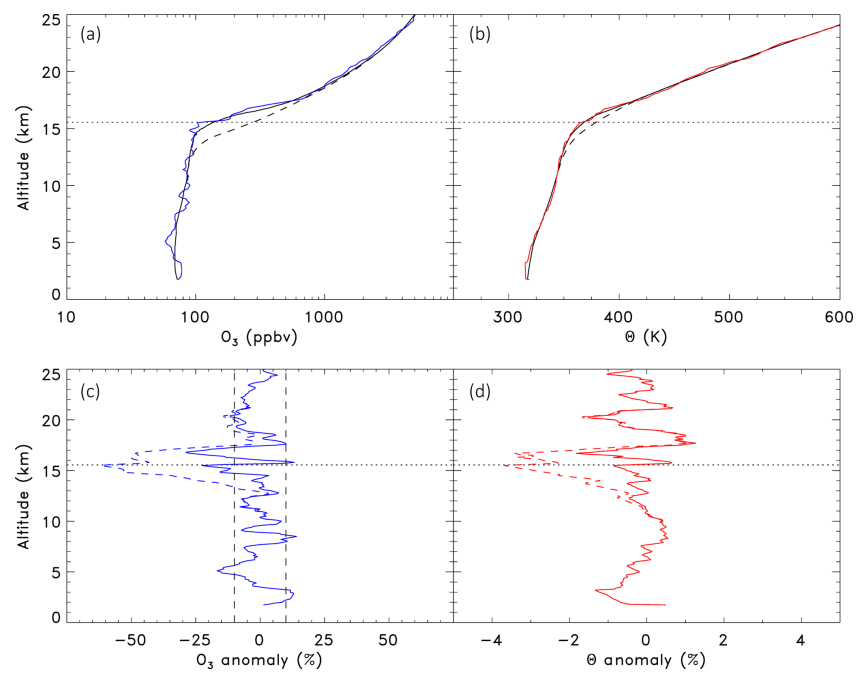

Figure 2. Vertical profiles of ozone (a, solid blue) and potential temperature (b, solid red) measured from Boulder, $\mathrm{CO}$, on $6 \mathrm{Au}-$ gust 2008. Both panels also show basic states calculated using a fixed-width filter (dashed) and a variable-width filter (solid), as described in the text. The bottom two panels show anomalies based on the fixed-width (dashed) and variable-width (solid) filters for ozone (c, blue), and potential temperature (d, red). Vertical dashed lines for the ozone anomaly indicate the $\pm 10 \%$ threshold for laminae detection, and the horizontal dotted lines in all panels indicate the height of the lapse rate tropopause determined from this sounding.

wave activity using GPS temperature profiles. We explored several alternatives for deriving basic states and minimizing tropopause-related artifacts, ranging from piecewise polynomial fitting to the use of climatological means. An important drawback for many approaches is that they cannot accommodate the large degree of variability in the altitude of the tropopause; even seasonal climatologies do not reproduce tropopause variability to the extent needed to remove false laminae detections. We adopted a method for RIO SOL that identifies the primary tropopause for each profile using the World Meteorological Organization (WMO) lapse rate criterion (e.g., Homeyer et al., 2010), and then employs a variable boxcar with a maximum width of $6 \mathrm{~km}$ and a minimum width of $1.5 \mathrm{~km}$ at the tropopause level. The width varies linearly with altitude within $6 \mathrm{~km}$ on either side of the tropopause, such that the boxcar width is symmetric about the tropopause level. As shown in Fig. 2, this variable-width filtering method allows the basic states to track sharp gradient changes at the tropopause while still filtering enough small-scale variability to identify ozone laminae in the anomaly profiles. The use of a variable-width-smoothed basic state means that the detection sensitivity for laminae of varying thickness will change with altitude. Away from the tropopause where the filtering width is $6 \mathrm{~km}$, all lamina with vertical scales less than $\sim 2.5 \mathrm{~km}$ can be identified. Near the tropopause, however, the mean boxcar width is about $2.6 \mathrm{~km}$, which corresponds to a lamina detection threshold width of about $1.5 \mathrm{~km}$. In addition, soundings that contain multiple tropopauses (e.g., Schwartz et al., 2015) are often associated with complex vertical structures in ozone that may not be fully characterized by this laminae analysis.

The same variable-width smoothing procedure is used to identify laminae in the measured vertical profile of $\Theta$. A lamina detected in potential temperature that is coincident with a lamina in ozone provides evidence that the sampled air parcel was subjected to a vertical displacement associated with gravity wave (GW) activity. This method has been used extensively to examine GW signatures in ozonesonde data (e.g., Teitelbaum et al., 1994; Pierce and Grant, 1998; Thompson et al., 2007a) and in aircraft measurements of ozone (e.g., Alexander and Pfister, 1995), based on the expectation that

$\Theta^{\prime}=\chi^{\prime}\left[\frac{\partial \Theta_{\mathrm{s}}}{\partial z} / \frac{\partial \chi_{\mathrm{s}}}{\partial z}\right]$

where $z$ is altitude. Teitelbaum et al. (1996) discuss the general conditions under which this relationship holds, including the condition that the timescales for ozone photochemistry are much longer than the timescales relevant for transport by GW phenomena. They further note that these coincidences are more readily identified by scaling potential temperature perturbations to account for differences in the mean vertical gradients of $\Theta$ and $\chi$,

$R(z)=\left(\frac{1}{\chi_{\mathrm{s}}} \frac{\mathrm{d} \chi_{\mathrm{s}}}{\mathrm{d} z}\right) /\left(\frac{1}{\Theta_{\mathrm{s}}} \frac{\mathrm{d} \Theta_{\mathrm{s}}}{\mathrm{d} z}\right)$.

A similar scaling was employed by Ehhalt et al. (1983) to compare equivalent vertical displacements obtained from measured variances in long-lived stratospheric gases.

One of the most straightforward approaches for identifying coincidences in ozone and potential temperature laminae involves the spatial correlation between vertical profiles of $\chi^{\prime} / \chi_{\mathrm{s}}$ and $R \Theta^{\prime} / \Theta_{\mathrm{s}}$ over a limited vertical domain, for example, within $5 \mathrm{~km}$ wide sampling windows (e.g., Teitelbaum et al., 1994). Figure 3 shows a set of relative anomaly profiles along with the magnitude of the correlation coefficient computed within a $5 \mathrm{~km}$ wide vertical window centered at the given altitude. A correlation threshold of $r>0.7$ has been shown to be a reliable indicator for GW-induced laminae in ozone (e.g., Pierce and Grant, 1998). One complication with this approach arises when multiple laminae appear within the same correlation window. For example, in Fig. 3 the central altitudes of laminae labeled 2 through 5 are close enough to cause interference in gauging the true correlation within individual laminae. We adopted a different approach for RIO SOL, by correlating over the extent of the laminar feature (where the amplitude exceeds $10 \%$ ) or over a $2 \mathrm{~km}$ window, whichever is larger. Sensitivity experiments indicate that our approach for deriving basic states and for correlating over more limited vertical domains is more consistent with previous analyses if we adopt a threshold of $r \geq 0.65$. In Fig. 3, RIO SOL detects GW ozone lamina (labeled 1 and 3) near 


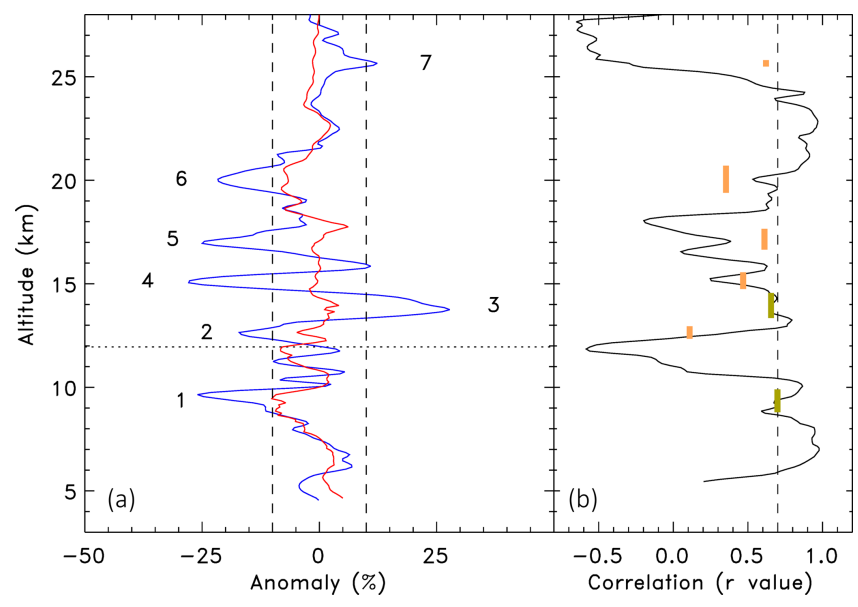

Figure 3. Panel (a) shows vertical profiles of ozone (blue) and scaled potential temperature anomalies (red) from a Boulder ozonesonde sounding on 4 May 2006. Vertical dashed lines represent a $10 \%$ amplitude threshold for defining laminae, and seven identified laminae are indicated by number. Panel (b) shows the correlation coefficient calculated between ozone and potential temperature anomalies using a $5 \mathrm{~km}$ wide sliding vertical window (solid curve), and alternatively from windows centered on individual laminae (orange and green bars). The dashed vertical line indicates the 0.7 threshold used for identifying gravity wave ozone laminae with the $5 \mathrm{~km}$ sliding window technique. For correlations over individual laminae, a 0.65 threshold value is adopted, and laminae meeting or exceeding this threshold are indicated by the green bars and classified as GW laminae, while correlations below 0.65 are indicated by orange bars and classified as NGW laminae.

9.5 and $14 \mathrm{~km}$ altitude with the application of the $r \geq 0.65$ threshold. Laminae for which ozone anomalies are not significantly correlated with scaled potential temperature anomalies $(r<0.65)$ are classified as non-gravity wave (NGW) laminae, as there is no evidence that the generation mechanism is associated with GW activity.

In order to examine the detection sensitivity for laminae, we constructed a set of 150 simulated ozone and temperature profiles using climatological values representing tropical, midlatitude summer, and midlatitude winter means (Anderson et al., 1986) and introduced localized ozone perturbations at random altitudes and over a random sample of amplitudes and widths. The perturbations were either triangular or Gaussian in shape. The simulated profiles were then analyzed using RIO SOL. Figure 4 shows two examples from the simulations and analysis. In the first example, three laminae were introduced to a tropical basic state and RIO SOL accurately characterized the anomalies (Fig. 4a and b). The amplitudes, widths, and central altitudes of positive and negative laminae are derived to within a few percent.

The second example is taken from a midlatitude simulation and highlights one of the weaknesses of the filter and difference approach. A large amplitude lamina (e.g., near $18.5 \mathrm{~km}$ in Fig. $4 \mathrm{c}$ and d) can shift the derived basic state

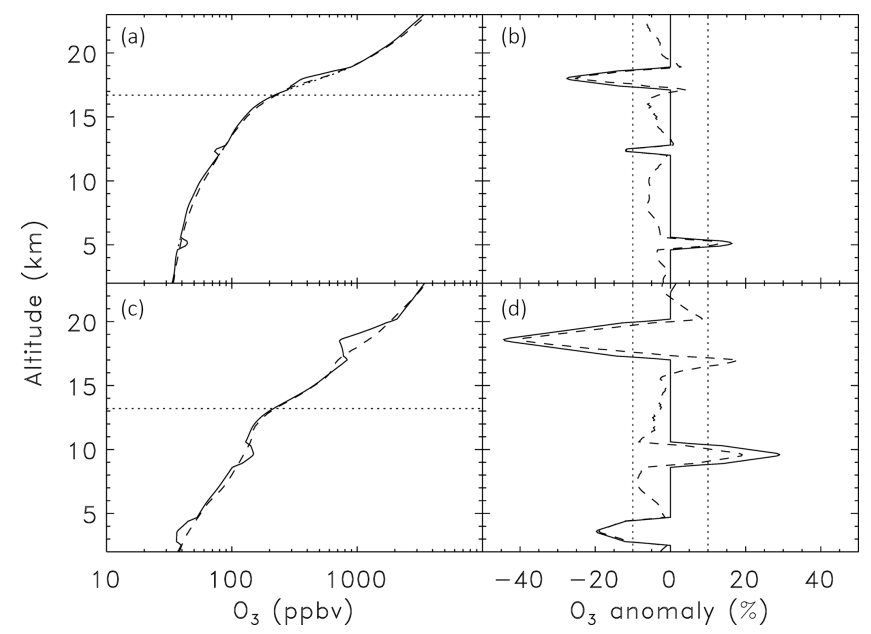

Figure 4. Two simulated ozone profiles with randomly placed laminae applied to a tropical basic state (a, b), and to a midlatitude basic state (c, d). In each case, panels (a) and (c) show the simulated ozone (solid) and the derived basic state (dashed), while panels (b) and (d) show the actual anomaly profile for each simulation (solid), along with the derived anomaly profile (dashed). Horizontal dotted lines in panels (a) and (c) denote the tropopause level, and vertical dotted lines in panels (b) and (d) denote the $10 \%$ anomaly threshold used for detecting ozone laminae.

enough to produce pairs or triplets of laminae in the derived perturbation profile. This effect can be seen in Fig. 4 by the appearance of a false positive lamina near $17 \mathrm{~km}$, which is an artifact produced by the large negative laminae immediately above it. False lamina detections accounted for nearly $25 \%$ of the total number of laminae identified in the simulations, with no altitude dependence in the number of false detections. This is in contrast to the fixed $6 \mathrm{~km}$ width smoothing method described in Sect. 3, which generates false laminae detections at the tropopause in nearly every profile. As expected, the proportion of false detections grows to nearly $50 \%$ as the lamina amplitude threshold is reduced from $10 \%$ to $5 \%$. It should be noted that the overall false detection rate is a direct consequence of how these simulations are designed. Most false detections are associated with a single large amplitude lamina in the simulation. Although we expect that the true number of false detections in observed ozone profiles is likely smaller, this effect is impossible to quantify because there is no way to directly observe the basic state.

In terms of positive identification of true features, the detection rate was $79 \%$ for all simulated laminae with amplitudes larger than $10 \%$ and widths between 0.2 and $2.5 \mathrm{~km}$. The detected fraction was degraded to about $60 \%$ for those laminae within $\pm 2 \mathrm{~km}$ of the tropopause, primarily because of the reduced filtering width used to derive the basic states near the tropopause. At all other altitudes, roughly half of the non-detections arose from simulations involving two or more laminae occurring in close proximity (within a few kilome- 
ters' altitude) which were counted as a single lamina in the identification process. Most of the remaining non-detections were due to simulated laminae with amplitudes just above the $10 \%$ threshold that were not counted because the derived amplitudes for these laminae fell just below $10 \%$. On average, there is a $2 \%-4 \%$ low bias in derived amplitudes using our version of the filter and difference method, and there is a tendency to underestimate widths by 0.1 to $0.2 \mathrm{~km}$ compared to the simulated inputs. Both of these small biases can be seen in some of the simulated laminae shown in Fig. 4, and they are an inevitable result of low-pass filtering to determine the basic state. Laminae altitudes are, however, accurately identified to within $\pm 0.1 \mathrm{~km}$.

One factor that may introduce a systematic offset to laminae central altitudes is the finite response time of the ozonesonde. Sonde ascent rates are consistently $4-6 \mathrm{~m} \mathrm{~s}^{-1}$ and response timescales are $\sim 25 \mathrm{~s}$, leading to a possible systematic bias of between +100 and $+150 \mathrm{~m}$ in altitude. Note that the offset is unlikely to be any bigger than this because we consistently find gravity wave laminae for which the ozone and $\Theta$ perturbations (which are based on temperature with response times on the order of a few seconds) are very well correlated on a $100 \mathrm{~m}$ grid, with no systematic altitude offsets. Given the $1 \mathrm{~Hz}$ sampling for the raw data, the effect of variations in ascent rate which can act to smooth measured profiles or to limit the resolving of laminar features, with scales greater than $0.2 \mathrm{~km}$, is minimal. There are also rare, but documented (e.g., Morris et al., 2010), measurement artifacts that could be mistakenly identified as ozone laminae. In the case of $\mathrm{SO}_{2}$ interference observed by Morris et al. (2010), RIO SOL would interpret apparent ozone "notches" as negative NGW ozone laminae.

\section{Results}

\subsection{Overall statistics for ozone laminae}

The RIO SOL analysis was applied to 1138 ozone soundings from Boulder, Colorado. As discussed in Sect. 2, these were obtained on a $\sim$ weekly basis between the years 1991 and 2015. A total of 9952 ozone laminae were identified, corresponding to a mean number of 8.7 laminae per sounding. The variability in the number of lamina per sounding was very close to a normal distribution about the mean, with a standard deviation of 2.3 laminae. There were no soundings with fewer than 2 or with more than 16 laminae detections.

There are considerable differences in the frequency of lamina detections with respect to altitude, season, and lamina type. The number of laminae observations per sounding within $1 \mathrm{~km}$ thick altitude bins relative to the WMO tropopause is shown in Fig. 5. The occurrence frequency for all ozone laminae maximizes near the tropopause and is roughly evenly distributed above and below the tropopause. Over $60 \%$ of all laminae were observed within $5 \mathrm{~km}$ of the

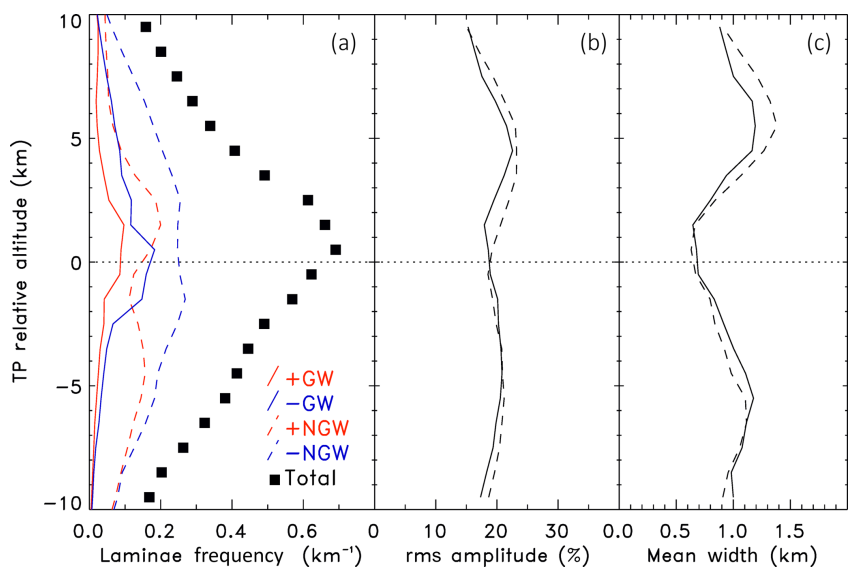

Figure 5. Vertical profiles of ozone laminae characteristics in altitude coordinates relative to the WMO tropopause. Panel (a) shows laminae frequency as the number of laminae detected per sounding within $1 \mathrm{~km}$ wide altitude bins. Black squares are for all laminae types and signs. Solid lines show frequencies of GW laminae, dashed lines indicate NGW laminae, and red and blue colors indicate positive and negative anomalies, respectively. Panels (b) and (c) show profiles of rms amplitudes and mean widths, respectively. The rms amplitudes are derived from the square of the mean relative anomaly within each lamina and averaged over all laminae detected within corresponding relative altitude bins. Widths are defined as the full altitude range in which the anomaly amplitude exceeds $10 \%$ (along consecutive $100 \mathrm{~m}$ sampling intervals), with a minimum restriction of $0.2 \mathrm{~km}$. As with panel (a), solid and dashed curves denote GW and NGW laminae, respectively.

tropopause. Our simulations (discussed above) strongly suggest that this is not an artifact caused by the tropopause, as the false detection rate for simulated ozone laminae was independent of altitude.

Figure 5 also displays occurrence frequencies for $\mathrm{GW}$ and NGW laminae, segregated by positive $(+\mathrm{GW},+\mathrm{NGW})$ or negative anomalies $(-\mathrm{GW},-\mathrm{NGW})$ with respect to the basic states. The most common lamina type is -NGW, which accounts for nearly half of all laminae detected outside of the tropopause region. Within $2 \mathrm{~km}$ of the tropopause, higher frequencies of $+\mathrm{GW}$ and $-\mathrm{GW}$ lamina contribute a more significant amount to the total. Over all altitudes, $28 \%$ of all laminae are the GW type and $72 \%$ are NGW laminae. Negative anomaly laminae outnumber positive anomaly laminae at most levels, and overall we detect about $15 \%$ more negative anomaly laminae.

Two of the most important characteristics of a laminar structure are its amplitude and thickness (or width). Figure 5 includes panels for the vertical distributions of the root mean square (rms) amplitudes and widths of detected lamina. For both rms amplitudes and widths, no significant differences were found between positive and negative anomaly laminae. The amplitude of a lamina is defined by the mean of the perturbation taken over the full altitude range in which the perturbation magnitude exceeds the $10 \%$ minimum threshold. 
Figure 5 shows that rms amplitudes are closely matched between GW and NGW laminae, with values between $15 \%$ and $20 \%$ in the troposphere and an overall tendency for larger amplitudes in the LS. The mean rms amplitude taken over all altitudes and laminae type is $20 \%$. The amplitude distribution is skewed by the presence of larger-amplitude ( $>40 \%)$ laminae that are seen in $\sim 2 \%$ of the soundings. These largeamplitude laminae are most often observed in the LS.

We define laminae widths by the continuous range of altitude levels over which the $10 \%$ minimum amplitude threshold is met in the anomaly profile. Figure 5 shows that average widths for laminae at Boulder are about $1 \mathrm{~km}$ in the troposphere, decreasing to $\sim 0.7 \mathrm{~km}$ near the tropopause and increasing again in the stratosphere (as noted below, a large fraction of this variation is a result of the detection method). The largest mean widths $(\sim 1.4 \mathrm{~km})$ were found for NGW laminae occurring about $5 \mathrm{~km}$ above the tropopause. As with amplitudes, no significant differences were found between the mean widths of positive and negative anomalies.

The frequency distribution of laminae widths is shown in Fig. 6. It varies with relative altitude as expected because of the variation in basic state smoothing parameters with respect to the tropopause. At relative altitudes larger than $\pm 5 \mathrm{~km}$, the distribution has a significant tail in which lamina widths up to $2.5 \mathrm{~km}$ are observed. Closer to the tropopause, we find a truncation of the width distribution around $1.5 \mathrm{~km}$ results from changing the filtering parameters for the basic states. If we assume that distribution of laminae widths far from the tropopause is representative of the entire profile, then we can estimate that roughly $16 \%$ of ozone laminae near the tropopause may not be identified because their widths are larger than our upper detection limit in this region. This undetected fraction estimated from Fig. 6 is consistent with the laminae simulations discussed above, in which the fraction of undetected laminae increased by $19 \%$ within $2 \mathrm{~km}$ of the tropopause. It should be noted, however, that the simulated negative lamina at $18 \mathrm{~km}$ in Fig. 4 is within $1.2 \mathrm{~km}$ of the tropical tropopause, and it is accurately characterized by RIO SOL. On the narrow side of the width distribution, extrapolation of the smoothly decreasing widths below modal values of $\sim 0.4 \mathrm{~km}$ at all altitudes yields a detection loss rate of about $2 \%-4 \%$ due to lamina with widths narrower than $0.2 \mathrm{~km}$.

Figure 6 also shows the frequency distribution of laminae amplitudes. Note that the distribution is truncated at $10 \%$ by the minimum threshold used for lamina detection. Sensitivity runs using smaller minimum thresholds indicate a significant number of small (5\%-10\% amplitude) laminae fall below our $10 \%$ minimum, as indicated in Fig. 6. A mean of about 12 laminae are detected per sounding using a $5 \%$ minimum amplitude threshold, an increase of about $40 \%$ laminae over using a $10 \%$ threshold. As discussed above, the fraction of false detections grows with decreasing amplitude threshold, so that the frequency estimate for amplitudes between $5 \%$
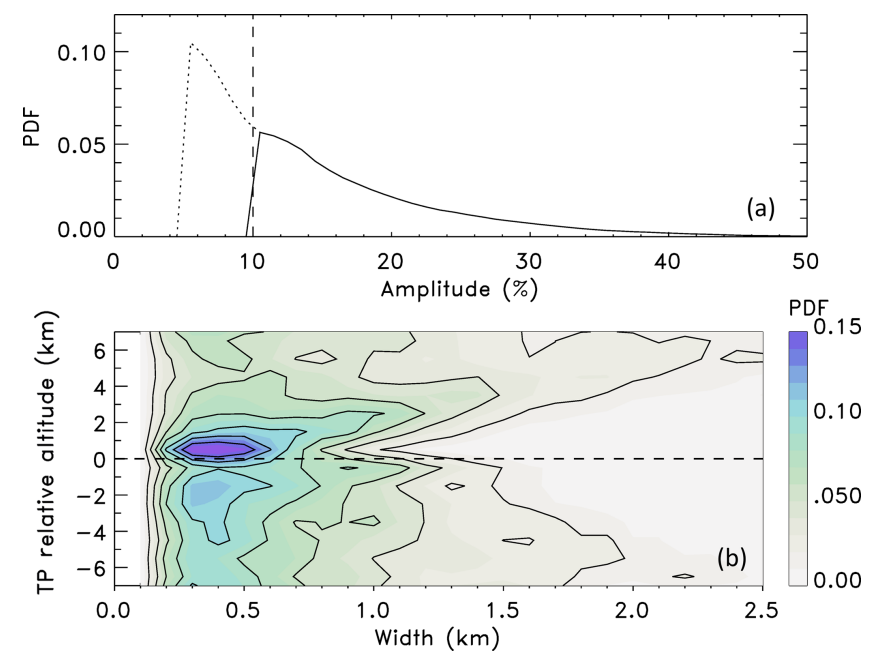

Figure 6. Probability density function (PDF) of the amplitude distribution for all ozone laminae (a) and contour PDF of width distribution for ozone laminae versus altitude relative to the WMO tropopause (b). For the amplitudes, the standard $10 \%$ detection threshold is indicated by the vertical dashed line and the solid curve shows the amplitude distribution using this criterion. The dotted curve shows the extension of the amplitude PDF if a $5 \%$ detection threshold is employed. For the width PDF, contours are separated by 0.02 , and the black dashed line indicates the tropopause level.

and $10 \%$ shown in Fig. 6 should be regarded as an upper limit on the true occurrence of small-amplitude laminae.

The above statistics for Boulder may be contrasted with those obtained using previous methodologies, namely the use of a fixed width, $6 \mathrm{~km}$ boxcar filter for the basic state and a $5 \mathrm{~km}$ wide correlation window for $\mathrm{O}_{3}$ and $\Theta$ anomalies. For this particular method, the total number of laminae detected is $25 \%$ smaller and their mean widths are more than twice as large as those from RIO SOL shown in Fig. 5, ranging from $1 \mathrm{~km}$ up to a maximum of $3 \mathrm{~km}$ at the tropopause. These differences can be attributed to the dominating influence of tropopause-induced laminae for the case of a fixedwidth boxcar. The apparent tropopause lamina appears in over half of the soundings and it is sufficiently wide to mask or absorb any other individual laminae that may be present within $2-3 \mathrm{~km}$ of the tropopause. Not surprisingly, we also detect fewer overall positive laminae when using the fixedwidth boxcar. There are also changes to the relative fraction of GW and NGW laminae when using a $5 \mathrm{~km}$ wide correlation window; relatively more GW laminae are detected and this fraction maximizes at the tropopause level in association with the aforementioned spurious tropopause-induced laminae in both $\mathrm{O}_{3}$ and $\Theta$.

A preliminary analysis has also been done using RIO SOL in its standard configuration for other measurement sites at midlatitude and low-latitude stations, and the results appear to be similar in accuracy to those from Boulder. At Pago Pago, Samoa, we find comparable statistics with a slightly 
higher overall frequency of laminae (nearly 10 per profile), a $30 \% \mathrm{GW}$ fraction, and a similar altitude distribution relative to the tropopause. On the other hand, when applying RIO SOL to winter-spring soundings in and around the Antarctic polar vortex or during particular cold periods in the Arctic winter, the criteria and thresholds for both ozone laminae and the tropopause would likely require significant changes in order to maintain a robust analysis, especially under conditions of significant ozone depletion and/or changes to the thermal structure of the lower stratosphere. A detailed comparison of ozone laminae from different measurement sites is planned for future investigations, but in this paper, our emphasis is on a description of techniques and on the climatology from Boulder.

\subsection{Basic states and ozone variance}

As discussed in Sect. 3, the filter and difference approach produces basic state profiles that can be used to quantify the fraction of overall variability in ozone attributable to laminar features in the profile. Figure 7 shows the climatological means and standard deviations of basic states for each of the four seasons (December-January-February is denoted by DJF, etc.). These are displayed in altitude coordinates rather than tropopause-relative coordinates in order to highlight seasonal differences. Because of the filtering methods used to derive these basic states, all of the basic state variability in the UT arises from ozone changes occurring on vertical scales larger than $2-3 \mathrm{~km}$. The mean basic states are nearly identical to climatological seasonal means obtained from the raw data, so that many of the expected seasonal effects are seen in the mean basic state profiles. For example, larger ozone mixing ratios occur during winter and spring in the 10 to $20 \mathrm{~km}$ altitude range as a result of stratospheric transport and seasonal changes in the tropopause height. This seasonality can be quantified by the standard deviation of the seasonal basic states at each altitude, as shown in Fig. 7, and can be directly compared with the intra-seasonal (i.e., within each season) variability derived from the standard deviation of each of the seasonal mean profiles. As noted above, the seasonal component of ozone variability is largest between 12 and $16 \mathrm{~km}$ altitude. However, the intra-seasonal basic state variability tends to follow the climatological tropopause and maximizes in the UT about 1-2 km below the WMO tropopause. During winter and spring, there is a secondary increase in LS variability $(12-15 \mathrm{~km})$, which is likely to be related to deep stratospheric intrusions of tropical/subtropical air like those investigated by Reid et al. (2000).

In summary, we expect contributions to the total intraseasonal ozone variance arising from three types of features: (i) detected laminae with widths between 0.2 and $2.5 \mathrm{~km}$ and amplitudes greater than $10 \%$, (ii) all variations with larger vertical scales $(>2.5 \mathrm{~km})$, and (iii) small-amplitude $(<10 \%)$ features across all vertical scales. Assuming that the total intra-seasonal ozone variance $\sigma_{\mathrm{T}}^{2}$ can be effectively

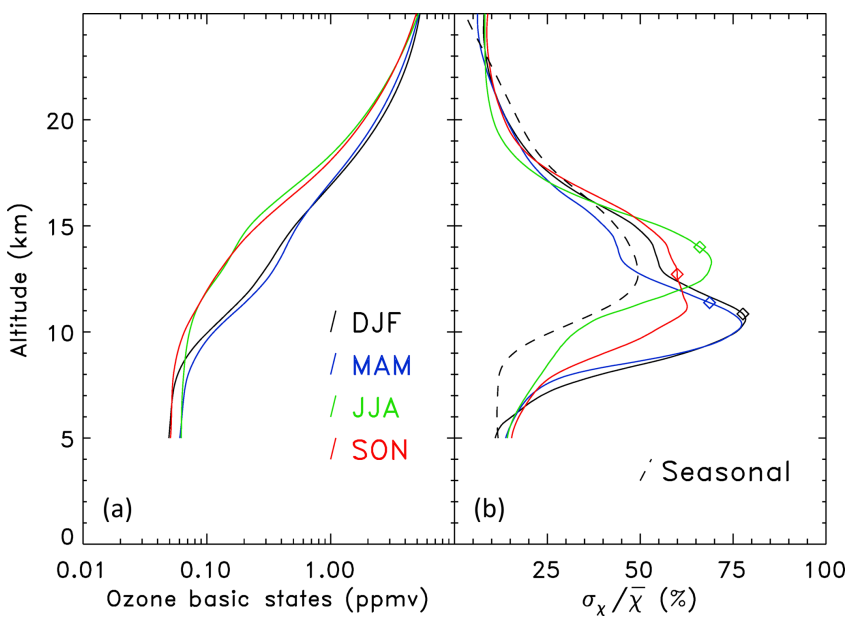

Figure 7. Seasonal means of ozone basic states profiles from Boulder over the years 1991-2015 (a) and normalized standard deviations of the basic states (b). The means and intra-seasonal standard deviations were taken over the periods December-February (DJF, black), March-May (MAM, blue), June-August (JJA, green), and September-November (SON, red). The standard deviations were normalized by mean values at each altitude, and seasonal mean tropopause heights are indicated by colored triangles. Also shown is comparable magnitude of the seasonal variation in basic states (dashed curve, b), estimated from the variance in the four seasonal basic states and normalized by the annual mean. Note that this seasonal magnitude is equivalent to $A_{\mathrm{p}} / \sqrt{ } 2$ for a cosine seasonal variation, where $A_{\mathrm{p}}$ is the peak relative amplitude.

decomposed into these components, then

$\left(\sigma_{T} / \chi\right)^{2}=(\bar{A})^{2}+\left(\sigma_{\mathrm{S}} / \chi\right)^{2}+(\bar{\delta})^{2}$,

where $\bar{A}$ is the rms amplitude of detected laminae, $\sigma_{\mathrm{s}}^{2}$ is the variance in the basic state profile, and $\bar{\delta}$ is the normalized variance due to small-amplitude $(<10 \%)$ features. The left side and the two largest terms on the right side of Eq. (3) are shown in Fig. 8 for the seasons of DJF and JJA. Raw ozone data were used to calculate $\sigma_{\mathrm{T}}^{2}$, while $(\bar{A})^{2}$ and $\sigma_{\mathrm{s}}^{2}$ were derived from the laminae amplitudes and basic state outputs of the RIO SOL analysis. Figure 8 shows that the total variance in ozone is generally controlled by large vertical-scale changes near and immediately below the tropopause. Laminae make up an important fraction of the total variance, however, and these features can be the dominant mode of ozone variability in the middle troposphere and lower stratospheric regions. The contribution from small-amplitude features $(\bar{\delta})^{2}$ was calculated from the results of the threshold sensitivity experiments discussed above (or could also be estimated as a residual from Eq. 3), and this contribution is typically between $0 \%$ and $5 \%$ of the total variance. Figure 8 also shows seasonal and altitude means of the contributions from all three terms on the right side of Eq. (3), indicated within boundaries of a coordinate system defined by the amplitude and the vertical scale of ozone variations. Our results 

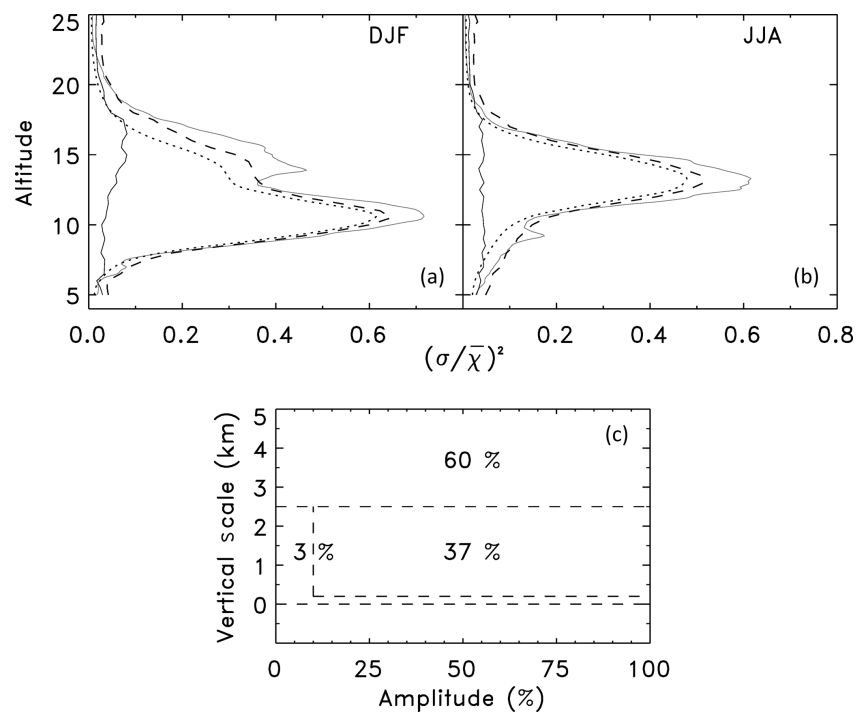

Figure 8. Normalized seasonal variances in ozone for DJF (a) and JJA (b). Plotted are the normalized total variance (solid gray), basic state variance (dotted), laminae variance (solid black), and the sum of basic state and laminae variances (dashed). Panel (c) shows the annual mean contributions to the total variance between 5 and $25 \mathrm{~km}$ altitude, as a function of amplitude and the vertical scale of features in the ozonesonde profile.

indicate that, on average, more than half of the intra-seasonal variance in ozone between 5 and $25 \mathrm{~km}$ altitude is due to large-scale changes in the basic state, and that slightly over one-third of ozone variations are due to laminar features that are identified by RIO SOL.

\subsection{Boulder laminae climatology}

We examine here how the frequency of detected laminae varies with altitude and season. Figure 9 shows monthly mean frequencies relative to the WMO tropopause for GW and for NGW ozone laminae. Consistent with Fig. 5, GW laminae are most often observed within $2 \mathrm{~km}$ of the tropopause, whereas NGW laminae are more evenly distributed throughout the UTLS. Throughout most of the year, the GW frequency distribution maximizes slightly above the tropopause, while the NGW frequency is larger below the tropopause. This situation reverses during the months of June-September, when more GW laminae are detected below the tropopause and most NGW laminae are found above the tropopause.

Climatologies of gravity wave momentum fluxes indicate a wintertime maximum in the LS for this location (e.g., Geller et al., 2013). However, it should be noted that while our ozone GW laminae climatology is expected to be related to the overall level of gravity wave activity, there are other factors that can influence whether a GW lamina in ozone is generated at the location of an ozonesonde profile in the first place, and then whether it will be detected by RIO SOL. For

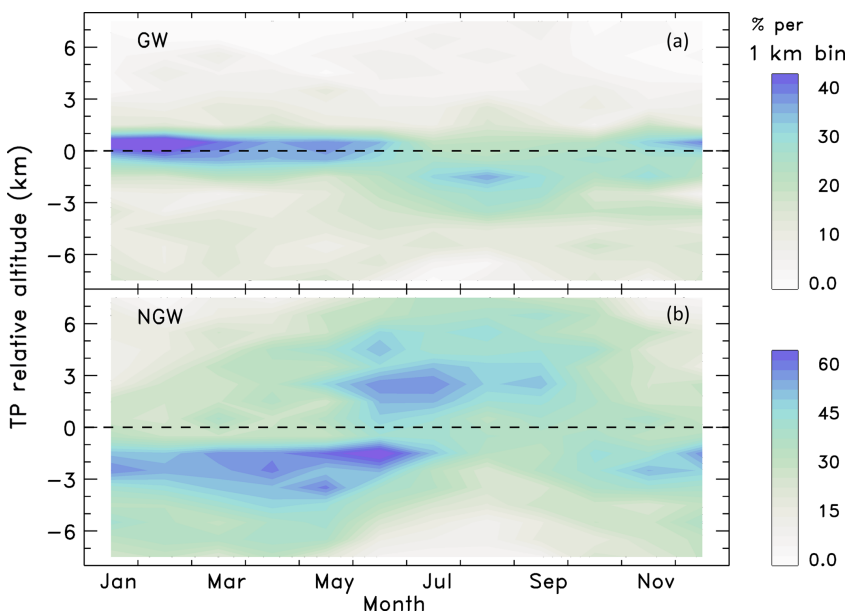

Figure 9. Climatology of ozone laminae frequency at Boulder, CO, as a function of month and altitude relative to the WMO tropopause for GW (a) and NGW (b) laminae. Frequency is expressed as the percent of soundings that contain one or more GW or NGW laminae within $1 \mathrm{~km}$ altitude bins relative to the tropopause. Note the different scales between GW and NGW frequencies.

example, our simulations suggest that GW laminae are more readily detected and identified as such in regions where background vertical gradients of ozone and potential temperature are both large, such as in the LS region.

The distribution of NGW laminae stands in stark contrast to that of GW laminae, and, as noted in the Introduction, the generating mechanisms for NGW laminae are much more uncertain. Previous analyses have used maximum correlation threshold criteria between ozone and potential temperature to infer the influence of Rossby waves on ozone (e.g., Pierce and Grant, 1998; Thompson et al., 2007a). We have not adopted this approach in RIO SOL due to larger uncertainties in positively classifying these laminae using ozone and potential temperature alone, particularly since the connection between $\mathrm{O}_{3}$ and $\Theta$ is not as clear as indicated in Eq. (1) for GW ozone laminae. However, it is plausible that a significant fraction of NGW laminae are generated in processes associated with Rossby wave activity. The seasonality of Rossby wave breaking (RWB) in the UTLS at northern midlatitudes (e.g., Hitchman and Huesmann, 2007; Isotta et al., 2008) is similar to the seasonality of UT NGW ozone laminae seen in Fig. 9. Rossby wave breaking and stratosphere-troposphere exchange (STE) are both prevalent along the flanks of UT jets (Gettelman et al., 2011 and references therein), and studies of jets using meteorological reanalysis data show a maximum in subtropical UT jet frequencies near $30^{\circ}$ latitude from November through April in the Northern Hemisphere (Manney et al., 2011, 2014). An associated phenomenon of multiple tropopause events, which are often linked to tropopause folds and extratropical STE (e.g., Sprenger et al., 2003), also shows maximum frequencies during December-March on the northern flank of the subtropical jet maximum (e.g., Man- 
ney et al., 2014), and these events are responsible for a significant fraction of the variability in ozone and other trace gases in the tropopause region (Schwartz et al., 2015).

Mechanisms leading to the maximum in NGW laminae frequency in the LS during summer are more uncertain. Jing and Banerjee (2018) found a maximum in anticyclonic RWB on the 350 and $370 \mathrm{~K} \Theta$ surfaces during $\mathrm{NH}$ summer, and both of these surfaces are typically at or above the tropopause level over Boulder during summer. In addition, they showed that the zonal distribution of summer RWB favored those regions above and immediately upstream of Boulder. However, the production of laminar features in summertime LS ozone from other mechanisms cannot be ignored. Impacts on the composition of the midlatitude summer LS have been demonstrated from monsoon-related dynamics (e.g., Randel et al., 2010), deep summertime convection (e.g., Weinstock et al., 2007), and meridional transport from the tropical UT (e.g., Bönisch et al., 2009). Clearly, more work is needed to understand the full range of dynamical and chemical processes that may produce the range of laminar ozone features seen in these balloon profiles and in other ozone measurements. The development of methods to further classify NGW laminae and to associate mechanisms with their generation is a focus of ongoing work using RIO SOL.

\section{Conclusions}

We have described the RIO SOL analysis package for characterizing ozone laminae in balloon soundings and presented an analysis of the $\sim 25$-year ozonesonde dataset from Boulder, Colorado. RIO SOL involves an adaptation of the filter and difference approach used in previous studies of ozonesonde profiles, in which a unique basic state is generated for each ozone profile and laminae are identified as deviations from this basic state. The major improvements in RIO SOL include methods for improved sensitivity in identifying GW laminae using potential temperature from each sounding and for avoiding false detections of GW laminae near the thermal tropopause. The vertical gridding of the ozonesonde data and the filtering method constrain the range of vertical scales for identified laminae to between 0.2 and $2.5 \mathrm{~km}$. Simulations indicate that RIO SOL can reliably identify most of the ozone laminae with relative amplitudes greater than $10 \%$, and virtually all laminae above $20 \%$ amplitude.

The mean number of ozone laminae observed per sounding at Boulder is about nine. This is much higher than the number (one-two) reported by Reid and Vaughan (1991) and Krizan et al. (2015) from analyses of northern midlatitude soundings, but as noted in the Introduction, the fixed detection threshold used in these studies emphasized stratospheric ozone laminae at the expense of tropospheric laminae. Huang et al. (2015) used separate thresholds for the troposphere and the stratosphere and found a mean of 2.5 laminae per profile in the ozonesonde dataset from Huntsville, Alabama. This is still significantly less than the number of laminae detected at Boulder. The method used by Huang et al. (2015) limited the smallest scale of detected laminae to $0.5 \mathrm{~km}$ as compared to the $0.2 \mathrm{~km}$ limit used here; thus, it is likely that the difference can largely be explained by the detection of laminae at smaller scales and with smaller amplitudes (due to the use of a relative amplitude threshold in RIO SOL). The root-meansquare laminae amplitude at Boulder is about $20 \%$ relative to the basic state. This mean amplitude does not vary significantly with altitude. It is slightly larger than the $\sim 15 \%$ mean amplitude determined by Pierce and Grant (1998) for ozonesondes from Wallops Island, Virginia, although their identification method could have been impacted by interference near the tropopause. The mean width of ozone laminae, defined by the altitude range in which the anomaly amplitude exceeds $10 \%$, varies between 0.7 and $1.4 \mathrm{~km}$ depending on the altitude relative to the tropopause and is generally smallest near the tropopause. Some of the variation in mean width with altitude is a result of the filtering procedure used in RIO SOL.

Laminae statistics have been examined on a tropopauserelative altitude grid rather than on standard altitudes relative to the surface. This gridding better delineates the subset of laminae generated by primarily tropospheric mechanisms from those resulting from mainly stratospheric phenomena and facilitates the identification of STE processes. The occurrence frequency for ozone laminae shows a distinct maximum within $\sim 2 \mathrm{~km}$ of the tropopause and is nearly symmetric above and below the tropopause. GW laminae make up about one-third of all ozone laminae. These are most often detected near the tropopause in the lower stratosphere. NGW laminae are more abundant, and negative NGW are the most dominant laminar feature throughout the UTLS region.

The total variance in the Boulder ozonesonde dataset was decomposed into terms representing changes in the ozone basic state, changes due to the presence of ozone laminae, and changes due to weaker-amplitude $(<10 \%)$ features. Largescale changes in the basic state account for $60 \%$ of the total intra-seasonal ozone variance. The magnitudes of intraseasonal variations in basic states are comparable to those of the seasonal cycle. Laminae detected by RIO SOL are responsible for $37 \%$ of the total variance in ozone, and the remaining $3 \%$ is estimated to originate from smaller-scale features. Although they are not the dominant form of ozone variability, laminae must be considered in order to quantify ozone variability and trends in the UTLS region. Future research in this area should be directed towards methods for obtaining global laminae datasets, either from satellite measurements or from ozonesonde networks, and towards the development of improved techniques for unambiguous identification of the mechanisms responsible for generating NGW ozone laminae. 
Code and data availability. NOAA ozonesonde datasets may be accessed from the data archive maintained by the Ozone and Water Vapor Group at the NOAA Earth System Research Laboratory, Global Monitoring Division, at https://www.esrl.noaa.gov/ gmd/ozwv/ozsondes/ (Johnson et al., 2018). The RIO SOL analysis package is written in Interactive Data Language (IDL) programming code and is available upon request by contacting the lead author.

Author contributions. KM led the writing and analysis for the manuscript with significant contributions from GLM and IP and comments from all authors. ATG and AFJ developed major components of the RIO SOL analysis package in consultation with all authors. IP, BJJ, and AFJ provided ozonesonde data and advised on their use with RIO SOL.

Competing interests. The authors declare that they have no conflict of interest.

Acknowledgements. Partial support was provided by a subcontract to New Mexico Tech from the Microwave Limb Sounder group at the Jet Propulsion Laboratory, for undergraduate student research in atmospheric physics. Kenneth Minschwaner is grateful to Anne Thompson for valuable advice on ozonesonde flight operations, data analysis, and the study of ozone laminae.

Edited by: Andreas Hofzumahaus

Reviewed by: three anonymous referees

\section{References}

Alexander, M. J. and Pfister, L.: Gravity wave momentum flux in the lower stratosphere over convection, Geophys. Res. Lett., 22, 2029-2032, https://doi.org/10.1029/95GL01984, 1995.

Anderson, G. P., Clough, S. A., Kneizys, F. X., Chetwynd, J. H., and Shettle, E. P.: AFGL atmospheric constituent profiles (0120 km), Rep. AFGL-TR-86-0110, 43 pp., Air Force Geophys. Lab., Hanscom AFB, Mass., USA, 1986.

Appenzeller, C. and Holton, J. R.: Tracer lamination in the stratosphere: A global climatology, J. Geophys. Res., 102, 1355513569, 1997.

Bönisch, H., Engel, A., Curtius, J., Birner, Th., and Hoor, P.: Quantifying transport into the lowermost stratosphere using simultaneous in-situ measurements of $\mathrm{SF}_{6}$ and $\mathrm{CO}_{2}$, Atmos. Chem. Phys., 9, 5905-5919, https://doi.org/10.5194/acp-9-5905-2009, 2009.

Bowman, K. P., Pan, L. L., Campos, T., and Gao, R.: Observations of fine-scale transport structure in the upper troposphere from the High-performance Instrumented Airborne Platform for Environmental Research, J. Geophys. Res., 112, D18111, https://doi.org/10.1029/2007JD008685, 2007.

Deshler, T., Mercer, J. L., Smit, H. G. J., Stubi, R., Levrat, G., Johnson, B. J., Oltmans, S. J., Kivi, R., Thompson, A. M., Witte, J., Davies, J., Schmidlin, F. J., Brothers, G., and Sasaki, T.: Atmospheric comparison of electrochemical cell ozonesondes from different manufacturers, and with different cathode solution strengths: The Balloon Experiment on Standards for Ozonesondes, J. Geophys. Res., 113, D04307, https://doi.org/10.1029/2007JD008975, 2008.

Deshler, T., Stübi, R., Schmidlin, F. J., Mercer, J. L., Smit, H. G. J., Johnson, B. J., Kivi, R., and Nardi, B.: Methods to homogenize electrochemical concentration cell (ECC) ozonesonde measurements across changes in sensing solution concentration or ozonesonde manufacturer, Atmos. Meas. Tech., 10, 2021-2043, https://doi.org/10.5194/amt-10-2021-2017, 2017.

Dobson, G. M. B.: The laminated structure of ozone in the atmosphere, Q. J. Roy. Meteor. Soc., 99, 599-607, 1973.

Dütsch, H. A.: Two Years of Regular Ozone Soundings Over Boulder, Colorado, NCAR Tech Note 01, National Center for Atmospheric Research, Boulder, CO, USA, 1966.

Ehhalt, D. H., Röth, E. P., and Schmidt, U.: On the temporal variance of stratospheric trace gas concentrations, J. Atrnos. Chern. 1, 27-71, 1983.

Fairlie, T. D., Avery, M. A., Pierce, R. B., Al-Saadi, J., Dibb, J., and Sachse, G.: Impact of multiscale dynamical processes and mixing on the chemical composition of the upper troposphere and lower stratosphere during the Intercontinental Chemical Transport Experiment-North America, J. Geophys. Res., 112, D16S90, https://doi.org/10.1029/2006JD007923, 2007.

Geller, M. A., Alexander, M. J., Love, P. T., Bacmeister, J., Ern, M., Hertzog, A., Manzini, E., Preusse, P., Sato, K., Scaife, A. A., and Zhou, T.: A comparison between gravity wave momentum fluxes in observations and climate models, J. Climate, 26, 6383-6405, 2013.

Gettelman, A., Hoor, P., Pan, L. L., Randel, W. J., Hegglin, M. I., and Birner, T.: The extratropical upper troposphere and lower stratosphere, Rev. Geophys., 49, RG3003, https://doi.org/10.1029/2011RG000355, 2011.

Grant, W. B., Pierce, R. B., Oltmans, S. J., and Browell, E. V.: Seasonal evolution of total and gravity wave induced laminae in ozonesonde data in the tropics and subtropics, Geophys. Res. Lett., 25, 1863-1866, 1998.

Hassler, B., Petropavlovskikh, I., Staehelin, J., August, T., Bhartia, P. K., Clerbaux, C., Degenstein, D., Mazière, M. D., Dinelli, B. M., Dudhia, A., Dufour, G., Frith, S. M., Froidevaux, L., GodinBeekmann, S., Granville, J., Harris, N. R. P., Hoppel, K., Hubert, D., Kasai, Y., Kurylo, M. J., Kyrölä, E., Lambert, J.-C., Levelt, P. F., McElroy, C. T., McPeters, R. D., Munro, R., Nakajima, H., Parrish, A., Raspollini, P., Remsberg, E. E., Rosenlof, K. H., Rozanov, A., Sano, T., Sasano, Y., Shiotani, M., Smit, H. G. J., Stiller, G., Tamminen, J., Tarasick, D. W., Urban, J., van der A, R. J., Veefkind, J. P., Vigouroux, C., von Clarmann, T., von Savigny, C., Walker, K. A., Weber, M., Wild, J., and Zawodny, J. M.: Past changes in the vertical distribution of ozone - Part 1: Measurement techniques, uncertainties and availability, Atmos. Meas. Tech., 7, 1395-1427, https://doi.org/10.5194/amt-7-13952014, 2014.

Hitchman, M. H. and Huesmann, A. S.: A seasonal climatology of Rossby wave breaking in the 320-2000-K layer, J. Atmos. Sci., 64, 1922-1940, 2007.

Homeyer, C. R., Bowman, K. P., and Pan, L. L.: Extratropical tropopause transition layer characteristics from highresolution sounding data, J. Geophys. Res., 115, D13108, https://doi.org/10.1029/2009JD013664, 2010. 
Huang, G., Newchurch, M. J., Kuang, S., Buckley, P. I., Cantrell, W., and Wang, L: Definition and determination of ozone laminae using Continuous Wavelet Transform (CWT) analysis, Atmos. Environ., 104, 125-131, 2015.

Isotta, F., Martius, O., Sprenger, M., and Schwierz, C.: Long-term trends of synoptic-scale breaking Rossby waves in the Northern Hemisphere between 1958 and 2001, Int. J. Climatol., 28, 15511562, 2008.

Jing, P. and Banerjee, S.: Rossby wave breaking and isentropic stratosphere-troposphere exchange during 1981-2015 in the northern hemisphere, J. Geophys. Res., 123, 9011-9025, https://doi.org/10.1029/2018JD028997, 2018.

Johnson, B. J., Oltmans, S. J., Vömel, H., Smit, H. G. J., Deshler, T., and Kröger, C.: Electrochemical concentration cell (ECC) ozonesonde pump efficiency measurements and tests on the sensitivity to ozone of buffered and unbuffered ECC sensor cathode solutions, J. Geophys. Res., 107, 4393, https://doi.org/10.1029/2001JD000557, 2002.

Johnson, B. J., Cullis, P. D., and NOAA ESRL: Earth System Research Laboratory Ozone Water Vapor Group Ozonesonde Measurements, Version 1.0. NOAA National Centers for Environmental Information, https://doi.org/10.7289/V5CC0XZ1, 2018.

Komhyr, W. D.: Operations handbook-Ozone measurements to $40 \mathrm{~km}$ altitude with model $4 \mathrm{~A}$ electrochemical concentration cell (ECC) ozonesondes (used with $1680 \mathrm{MHz}$ radiosondes), NOAA Tech. Memo. ERL ARL-149, Air Resources Laboratory, Boulder, CO, USA, 1986.

Komhyr, W. D., Barnes, R. A., Brothers, G. B., Lathrop, J A., and Opperman, D. P.: Electrochemical concentration cell ozonesonde performance evaluation during STOIC 1989, J. Geophys. Res., 100, 9231-9244, 1995.

Krizan, P. and Lastovicka, J.: Trends in positive and negative ozone laminae in the Northern Hemisphere, J. Geophys. Res., 110, D10107, https://doi.org/10.1029/2004JD005477, 2005.

Krizan, P., Lastovicka, J., and Kozubek, M.: Size dependence of ozone lamina characteristics and their correlations, J. Atmos. Sol.-Terr. Phy., 132, 116-123, 2015.

Langford, A. O. and Reid, S. J.: Dissipation and mixing of a smallscale stratospheric intrusion in the upper troposphere, J. Geophys. Res., 103, 31265-31276, 1998.

Liu, S. C., Kley, D., McFarland, M., Mahlman, J. D., and Levy II, H.: On the origin of tropospheric ozone, J. Geophys. Res., 85, 7546-7552, 1980.

Manney, G. L., Bird, J. C., Donovan, D. P., Duck, T. J., Whiteway, J. A., Pal, S. R., and Carswell, A. I.: Modelling ozone laminae in ground-based Arctic wintertime observations using trajectory calculations and satellite data, J. Geophys. Res., 103, 5797-5814, 1998.

Manney, G. L., Michelsen, H. A., Irion, F. W., Toon, G. C., Gunson, M. R., and Roche, A. E.: Lamination and polar vortex development in fall from ATMOS long-lived trace gases observed during November 1994, J. Geophys. Res., 105, 29023-29038, 2000.

Manney, G. L., Hegglin, M. I., Daffer, W. H., Santee, M. L., Ray, E. A., Pawson, S., Schwartz, M. J., Boone, C. D., Froidevaux, L., Livesey, N. J., Read, W. G., and Walker, K. A.: Jet characterization in the upper troposphere/lower stratosphere (UTLS): applications to climatology and transport studies, Atmos. Chem. Phys., 11, 6115-6137, https://doi.org/10.5194/acp11-6115-2011, 2011.
Manney, G. L., Hegglin, M. I., Daffer, W. H., Schwartz, M. J., Santee, M. L., and Pawson, S.: Climatology of Upper Tropospheric/Lower Stratospheric (UTLS) Jets and Tropopauses in MERRA, J. Climate, 27, 3248-3271, 2014.

Minschwaner, K., Manney, G. L., Petropavlovskikh, I., Torres, L. A., Lawrence, Z. D., Sutherland, B., Thompson, A. M., Johnson, B. J., Butterfield, Z., Dubey, M. K., Froidevaux, L., Lambert, A., Read, W. G., and Schwartz, M. J.: Signature of a tropical Pacific cyclone in the composition of the upper troposphere over Socorro, NM, Geophys. Res. Lett., 42, 9530-9537, https://doi.org/10.1002/2015GL065824, 2015.

Morris, G. A., Komhyr, W. D., Hirokawa, J., Flynn, J., Lefer, B., Krotkov, N., and Ngan, F.: A balloon sounding technique for measuring $\mathrm{SO}_{2}$ plumes, J. Atmos. Ocean. Tech., 37, 1318-1330, 2010.

Olsen, M. A., Douglass, A. R., Schoeberl, M. E., Rodriguez, J. M., and Yoshida, Y.: Interannual variability of ozone in the winter lower stratosphere and the relationship to lamina and irreversible transport, J. Geophys. Res., 115, D15305, https://doi.org/10.1029/2009JD013004, 2010.

Orsolini, Y. J.: On the formation of ozone laminae at the edge of the Arctic polar vortex, Q. J. Roy. Meteor. Soc., 121, 1923-1941, 1995.

Pan, L. L., Randel, W. J., Gille, J. C., Hall, W. D., Nardi, B., Massie, S., Yudin, V., and Khosravi, R.: Tropospheric intrusions associated with the secondary tropopause, J. Geophys. Res., 114, D10302, https://doi.org/10.1029/2008JD011374, 2009.

Pierce, R. B. and Grant, W. B.: Seasonal evolution of Rossby and gravity wave induced laminae in ozonesonde data obtained from Wallops Island, Virginia, Geophys. Res. Lett., 25, 1859-1862, 1998.

Randel, W. J., Gille, J. C., Roche, A. E., Kumer, J. B., Mergenthaler, J. C., Waters, J. W., Fishbein, E. F., and Lahoz, W. A.: Stratospheric transport from the tropics to middle latitudes by planetary wave mixing, Nature, 365, 533-535, 1993.

Randel, W. J., Park, M., Emmons, L., Kinnison, D., Bernath, P., Walker, K. A., Boone, C., and Pumphrey, H.: Asian Monsoon Transport of Pollution to the Stratosphere, Science, 328, 611613, https://doi.org/10.1126/science.1182274, 2010.

Reid, S. J. and Vaughan, G.: Lamination in ozone profiles in the lower stratosphere, Q. J. Roy. Meteor. Soc., 17, 825-844, 1991.

Reid, S. J., Tuck, A. F., and Kiladis, G.: On the changing abundance of ozone minima at northern midlatitudes, J. Geophys. Res., 105, 12169-12180, 2000.

Schmidt, T., de la Torre, A., and Wickert, J.: Global gravity wave activity in the tropopause region from CHAMP radio occultation data, Geophys. Res. Lett., 35, L16807, https://doi.org/10.1029/2008GL034986, 2008.

Schwartz, M. J., Manney, G. L., Hegglin, M. I., Livesey, N. J., Santee, M. L., and Daffer, W. H.: Climatology and variability of trace gases in extratropical double-tropopause regions from MLS, HIRDLS, and ACE-FTS measurements, J. Geophys. Res. 120, 843-867, https://doi.org/10.1002/2014JD021964, 2015.

Selkirk, H. B., Vömel, H., Valverde Canossa, J. M., Pfister, L., Diaz, J. A., Fernández, W., Amador, J., Stolz, W., and Peng, G.: The detailed structure of the tropical upper troposphere and lower stratosphere as revealed by balloonsonde observations of water vapor, ozone, temperature and winds during the NASA 
TCSP and TC4 campaigns, J. Geophys. Res., 115, D00J19, https://doi.org/10.1029/2009JD013209, 2010.

Shimazaki, T.: The photochemical time constants of minor constituents and their families in the middle atmosphere, J. Atmos. Sol.-Terr. Phy., 46, 173-191, 1984.

Smit, H. G. J., Straeter, W., Johnson, B. J., Oltmans, S. J., Davies, J., Tarasick, D. W., Hoegger, B., Stubi, R., Schmidlin, F. J., Northam, T., Thompson, A. M., Witte, J. C., Boyd, I., and Posny, F.: Assessment of the performance of ECC-ozonesondes under quasi-flight conditions in the environmental simulation chamber: Insights from the Juelich Ozone Sonde Intercomparison Experiment (JOSIE), J. Geophys. Res., 112, D19306, https://doi.org/10.1029/2006JD007308, 2007.

Sprenger, M., Maspoli, M. C., and Wernli, H.: Tropopause folds and cross-tropopause exchange: A global investigation based upon ECMWF analyses for the time period March 2000 to February 2001, J. Geophys. Res., 108, 8518, https://doi.org/10.1029/2002JD002587, 2003.

Sterling, C. W., Johnson, B. J., Oltmans, S. J., Smit, H. G. J., Jordan, A. F., Cullis, P. D., Hall, E. G., Thompson, A. M., and Witte, J. C.: Homogenizing and estimating the uncertainty in NOAA's long-term vertical ozone profile records measured with the electrochemical concentration cell ozonesonde, Atmos. Meas. Tech., 11, 3661-3687, https://doi.org/10.5194/amt11-3661-2018, 2018.

Teitelbaum, H., Ovarlez, J., Kelder, H., and Lott, F.: Some observations of gravity-wave-induced structure in ozone and water vapour during EASOE, Geophys. Res. Lett., 21, 1483-1486, 1994.

Teitelbaum, H., Moustaoui, M., Ovarlez, J., and Kelder, H.: The role of atmospheric waves in the laminated structure of ozone profiles at high latitude, Tellus, 48A, 422-455, 1996.

Thompson, A. M., Stone, J. B., Witte, J. C., Miller, S. K., Pierce, R. B., Chatfield, R. B., Oltmans, S. J., Cooper, O. R., Loucks, A. L., Taubman, B. F., Johnson, B. J., Joseph, E., Kucsera, T. L., Merrill, J. T., Morris, G. A., Hersey, S., Forbes, G., Newchurch, M. J., Schmidlin, F. J., Tarasick, D. W., Thouret, V., and Cammas, J.-P.: Intercontinental Chemical Transport Experiment Ozonesonde Network Study (IONS) 2004: 1. Summertime upper troposphere/lower stratosphere ozone over northeastern North America, J. Geophys. Res., 112, D12S12, https://doi.org/10.1029/2006JD007441, 2007a.
Thompson, A. M., Stone, J. B., Witte, J. C., Miller, S. K., Oltmans, S. J., Kucsera, T. L., Ross, K. L., Pickering, K. E., Merrill, J. T., Forbes, G., Tarasick, D. W., Joseph, E., Schmidlin, F. J., McMillan, W. W., Warner, J., Hintsa, E. J., and Johnson, J. E.: Intercontinental Chemical Transport Experiment Ozonesonde Network Study (IONS) 2004: 2. Tropospheric ozone budgets and variability over northeastern North America, J. Geophys. Res., 112, D12S13, https://doi.org/10.1029/2006JD007670, 2007b.

Thompson, A. M., Allen, A. L., Lee, S., Miller, S. K., and Witte, J. C.: Gravity and Rossby wave signatures in the tropical troposphere and lower stratosphere based on Southern Hemisphere Additional Ozonesondes (SHADOZ), J. Geophys. Res., 116, D05302, https://doi.org/10.1029/2009JD013429, 2011.

Tomikawa, Y., Sato, K., Kita, K., Fujiwara, M., Yamamori, M., and Sano, T.: Formation of an ozone lamina due to differential advection revealed by intensive observations, J. Geophys. Res., 107, 4092, https://doi.org/10.1029/2001JD000386, 2002.

Tuck, A. F., Hovde, S. J., Kelly, K. K., Reid, S. J., Richard, E. C., Atlas, E. L., Donnelly, S. G., Stroud, V. R., Cziczo, D. J., Murphy, D. M., Thomson, D. S., Elkins, J. W., Moore, F. L., Ray, E. A., Mahoney, M. J., and Friedl, R. R.: Horizontal variability 1-2 km below the tropical tropopause, J. Geophys. Res., 109, D05310, https://doi.org/10.1029/2003JD003942, 2004.

Vogel, B., Günther, G., Müller, R., Grooß, J.-U., Hoor, P., Krämer, M., Müller, S., Zahn, A., and Riese, M.: Fast transport from Southeast Asia boundary layer sources to northern Europe: rapid uplift in typhoons and eastward eddy shedding of the Asian monsoon anticyclone, Atmos. Chem. Phys., 14, 12745-12762, https://doi.org/10.5194/acp-14-12745-2014, 2014.

Waugh, D. W.: Seasonal variation of isentropic transport out of the tropical stratosphere, J. Geophys. Res., 101, 4007-4023, 1996.

Weinstock, E. M., Pittman, J. V., Sayres, D. S., Smith, J. B., Anderson, J. G., Wofsy, S. C., Xueref, I., Gerbig, C., Daube, B. C., Pfister, L., Richard, E. C., Ridley, B. A., Weinheimer, A. J., Jost, H.-J., Lopez, J. P., Loewenstein, M., and Thompson, T. L.: Quantifying the impact of the North American monsoon and deep midlatitude convection on the subtropical lowermost stratosphere using in situ measurements, J. Geophys. Res., 112, D18310, https://doi.org/10.1029/2007JD008554, 2007. 